\title{
Gallbladder paraganglioma
}

\author{
İlhan Ece', Hüsnü Alptekin ${ }^{1}$, Zeliha Esin Çelik², Mustafa Șahin ${ }^{1}$
}

\begin{tabular}{|c|c|}
\hline ABSTRACT & $\begin{array}{l}\text { Gallbladder paraganglioma is a very rare tumor, and only a few cases have been reported. Most of these cases were } \\
\text { asymptomatic and found incidentally during operation. Our case involved a 57-year-old female patient complaining } \\
\text { of intermittent right upper quadrant pain. Preoperative imaging demonstrated a mass in the neck of the gallbladder. } \\
\text { Laparoscopic cholecystectomy was performed, and a frozen section of the gallbladder demonstrated a benign mass. } \\
\text { The postoperative pathologic examination reported gallbladder paraganglioma and chronic cholecystitis. Immunohis- } \\
\text { tochemically, the chief cells and sustentacular cells showed diffuse positivity with vimentin, synaptophysin, and S-100. }\end{array}$ \\
\hline & Keywords: Gallbladder, paraganglioma, intra-abdominal mass \\
\hline
\end{tabular}

'Department of General Surgery, Selçuk University Faculty of Medicine, Konya, Turkey 2Department of Pathology, Selçuk University Faculty of Medicine, Konya, Turkey

\section{Address for Correspondence İlhan Ece} e-mail: ilhanece@yahoo.com

Received: 17.02 .2014 Accepted: 10.04 .2014 Çevrimiçi Yayın Tarihi:08.09.2014

CCopyright 2015 by Turkish Surgical Association Available online at www.ulusalcerrahidergisi.org

\section{INTRODUCTION}

Paraganglia differentiate from neural crest cells during the embryonic period. Paragangliomas are unusual neoplasms originating from paraganglia (1). The paraganglion system consists of two cell types, called chief and sustentacular cells. The most common location of paraganglioma is the adrenal medulla, defined as pheochromocytoma. The second most frequent region is the carotid body; also, paragangliomas have been reported in the retroperitoneum, head, paranasal sinuses, bladder, and many different organs (2-4). Paragangliomas are very rare in the gallbladder. We aimed to present a non-functional gallbladder paraganglioma with a review of the literature.

\section{CASE PRESENTATION}

A 57-year-old female patient was admitted to the surgery clinic complaining of intermittent right upper quadrant pain associated with food taken for 6 months. Physical examination was unremarkable. Blood pressure was normal. The results of the laboratory tests were white blood cell (WBC) $7.5 \mathrm{~K} / \mathrm{UL}$, total bilirubin $0.9 \mathrm{mg} / \mathrm{dL}$, alanine aminotransferase (ALT) $17 \mathrm{U} / \mathrm{L}$, aspartate aminotransferase (AST) $17 \mathrm{U} / \mathrm{L}$, carcinoembryonic antigen (CEA) $1.49 \mathrm{ng} / \mathrm{mL}$, and carbohydrate antigen (CA) 19-9 $30 \mathrm{U} / \mathrm{mL}$. Abdominal ultrasonography showed multiple gallstones and a mass within the triangle of Calot. Abdominal computed tomography and magnetic resonance imaging demonstrated a 2-cm-diameter mass in the neck of gallbladder (Figure 1, 2). After obtaining written informed consent of the patient, laparoscopic cholecystectomy was planned by a team experienced in advanced laparoscopic procedures. During the laparoscopy, a mass of 2 centimeters in diameter was seen in the Hartmann pouch. Laparoscopic cholecystectomy was performed, and a frozen section of the gallbladder demonstrated a benign mass and chronic cholecystitis. The patient was discharged on the second postoperative day without any complication.

The pathological examination reported that macroscopically, the gallbladder dimensions were $8 \times 5.5 \mathrm{x}$ 0.2 centimeters, and a lot of stones were seen with a diameter of 1-3 millimeters. A well-circumscribed, round, 1.8-cm-diameter intramural mass was settled in the neck of the gallbladder.

On microscopic examination, the tumor was located in the muscularis propria and serosa of the gallbladder and composed of well-defined nests of chief cells with uniform nuclei and abundant granular basophilic cytoplasm and sustentacular cells around the chief cells (Figure 2A). A highly vascular stroma supported the tumoral nests. Immunohistochemically, the chief cells showed diffuse and strong cytoplasmic positivity with vimentin (Figure 2B) and synaptophysin (Figure 2C) and sustentacular cells stained with S-100 (Figure 2D). The chromaffin reaction was not positive in this case. However, tissues preserved in formaldehyde can induce a false-negative chromaffin reaction. No mitotic figure, nuclear atypia, or necrosis was detected. The tumor was diagnosed as 'paraganglioma.'

\section{DISCUSSION}

Gallbladder paraganglioma was first reported by Miller et al. (5) in 1972. In this case, a 3-cm-sized paraganglioma was discovered during a duodenal ulcer operation. Since then, 9 cases (including our case) of 


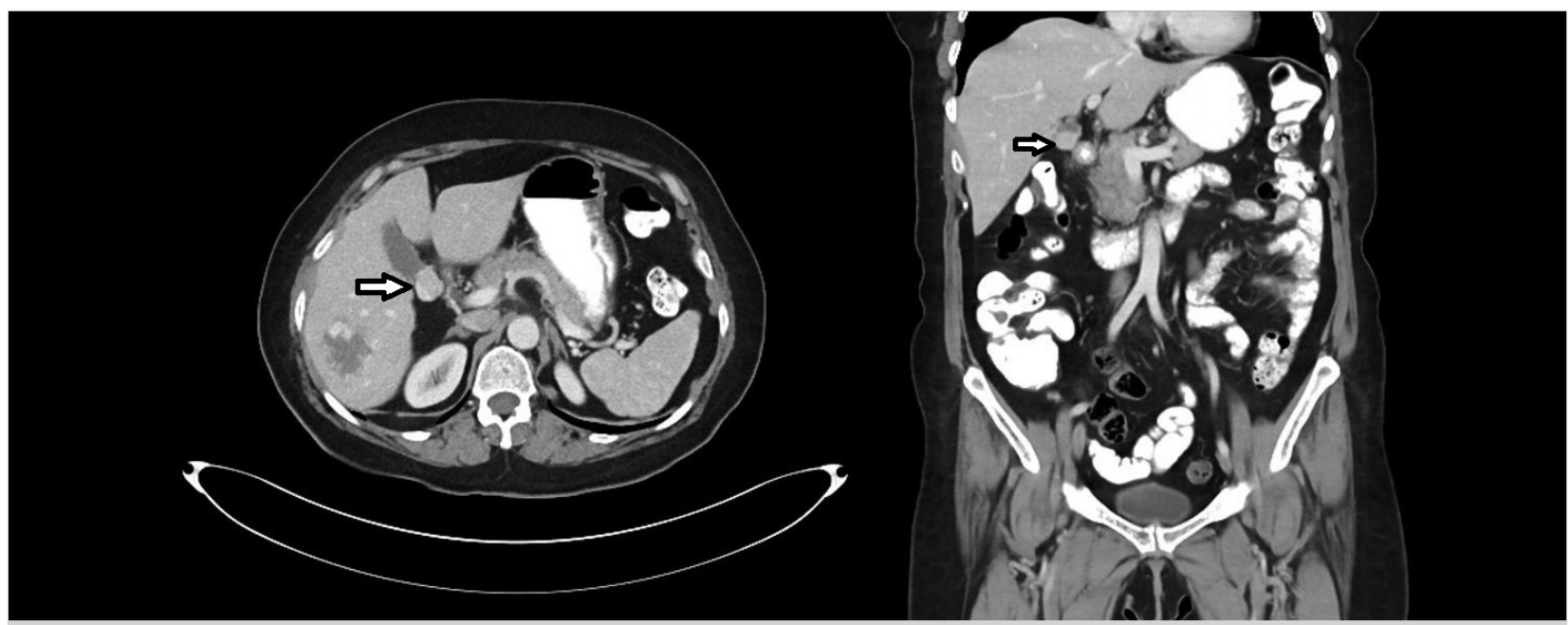

Figure 1. Computed tomography images of mass in the neck of gallbladder
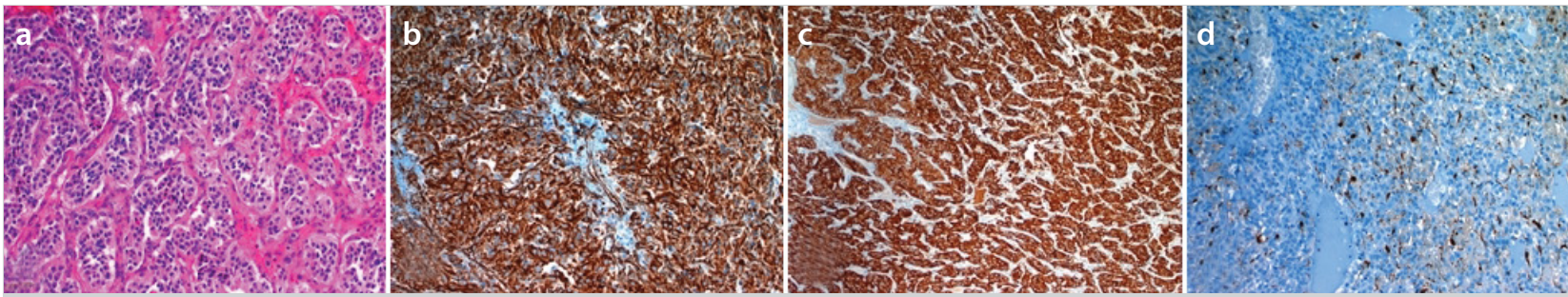

Figure 2. Well-defined nests of chief cells with uniform nuclei and abundant granular basophilic cytoplasm and sustentacular cells around the chief cells (a). The chief cells showed diffuse and strong cytoplasmic positivity with vimentin (b) and synaptophysin (c), and sustentacular cells stained with S-100 (d)

Table 1. Cases of gallbladder paraganglioma

\begin{tabular}{|l|lllll|} 
& Age/Sex & Radiologic finding & Presentation & Size (cm) & Location \\
\hline 1-Miller et al. (5) & $67 / M$ & Duodenal ulcer & Recurrent hematemesis & 3 & NM \\
\hline 2-Wolff (8) & 32/F & NM & Cholelithiasis & NM & Subserosal \\
\hline 3-Wolff (8) & 52/F & NM & Cholelithiasis & NM & Subserosal \\
\hline 4-Wolff (8) & 59/F & NM & Cholelithiasis & NM & Subserosal \\
\hline 5-Hirano (6) & $58 / F$ & Mass in the neck of gallbladder & Right hypochondrial pain & 1.3 & Submucosal \\
\hline 6-Cho et al. (7) & $45 / F$ & Mass in the fundus of gallbladder & Right upper quadrant pain & 2.5 & NM \\
\hline 7-Mehra et al. (10) & $36 / \mathrm{M}$ & None & None & 1.5 & Subserosal \\
\hline $\begin{array}{l}\text { 8-Rodríguez-Merchán } \\
\text { et al. (9) }\end{array}$ & $50 / F$ & $\begin{array}{l}\text { Cholelithiasis and intra- and } \\
\text { extrahepatic biliary dilatation }\end{array}$ & $\begin{array}{l}\text { Right upper quadrant pain } \\
\text { and vomiting }\end{array}$ & 1 & Subserosal \\
\hline
\end{tabular}

NM: not mentioned

gallbladder paraganglioma have been reported. The majority of cases presented with symptoms related to gallbladder disorder. Three cases presented with upper abdominal pain, and a mass was seen on radiologic investigation $(6,7)$. Four cases presented with cholelithiasis, and paraganglioma was found incidentally $(8,9)$, and one of the cases presented with recurrent hematemesis from cholecystoduodenal fistula; the ninth case of gallbladder paraganglioma was found incidentally during a Roux-en-Y gastric bypass operation for a morbidly obese patient (Table 1) (10). The majority of reported gallbladder paragangliomas is found incidentally during operations for other diseases, rather than the effect of catecholamine secreted from paraganglioma. All reported paraganglioma cases were non-functional. Our case was discovered with ultrasonography preoperatively and confirmed with computed tomography. Laparoscopic cholecystectomy was performed, and the frozen section showed a benign mass. There were no specific symptoms before the surgery, and no fluctuation of blood pressure during the operation indicated functional paraganglioma. Paraganglioma was diagnosed pathologically.

Most paragangliomas follow a benign clinical course, with only $10 \%$ shown to be malignant (5). There are no specific morphologic criteria to differentiate microscopically benign from malignant paraganglioma. The distinction between benign and malignant lesions is based on the presence of meta- 
static disease. Some authors reported that coarse nodularity, confluent necrosis, and decreased expression of neuropeptides could give a preview of malignancy (11). Other features suggestive of malignant behavior are decrease in sustentacular cells, alveolar pattern, high mitotic count (3/30 per highpower field), large size of the tumor, extra-adrenal location, hemorrhage and tumor necrosis, male sex, local aggressiveness, multicentricity, bilaterality, pleomorphism, and capsular and vascular invasion (11). DNA ploidy studies have suggested that malignant tumors are aneuploid, and benign tumors can be euploid or aneuploid.

In our case, the paraganglioma was well encapsulated, and it positively reacted immunohistochemically. The chief cells showed diffuse and strong cytoplasmic positivity with vimentin and synaptophysin, and sustentacular cells stained with S-100. Vascular invasion, tissue necrosis, and infiltrative growth pattern were not shown.

\section{CONCLUSION}

The prognosis and characteristics of paragangliomas can be understood clearly with the increasing number of cases; until then, gallbladder paragangliomas should be monitored more frequently.

Informed Consent: Written informed consent was obtained from patient who participated in this case.

Peer-review: Externally peer-reviewed.

Author Contributions: Concept - H.A.; Funding - I.E., Z.E.Ç.; Materials - Z.E.Ç.; Data Collection and/or Processing - I.E., Z.E.Ç.; Analysis and/or Interpretation - İ.E.; Literature Review - I.E., H.A.; Writer - İ.E., M.Ş.; Critical Review - H.A., M.Ş.
Conflict of Interest: No conflict of interest was declared by the authors.

Financial Disclosure: The authors declared that this study has received no financial support.

\section{REFERENCES}

1. Rodriguez-Cuevas H, Lau I, Rodriguez HP. High-altitude paragangliomas diagnostic and therapeutic considerations. Cancer 1986; 57: 672-676. [CrossRef]

2. Kliewer KE, Wen DR, Cancilla PA, Cochran AJ. Paragangliomas: assessment of prognosis by histologic, immunohistochemical, and ultrastructural techniques. Hum Pathol 1989; 20: 29-39. [CrossRef]

3. $\mathrm{Yu} \mathrm{BH}$, Sheng WQ, Wang J. Primary paraganglioma of thyroid gland: a clinicopathologic and immunohistochemical analysis of three cases with a review of the literature. Head Neck Pathol 2013; 7: 373-380. [CrossRef]

4. Ginderdeuren RV, Missotten GS, van den Oord J. Choroidal paraganglioma with metastases to the fellow eye. Case Rep Ophthalmol 2013; 4: 17-22. [CrossRef]

5. Miller TA,Weber TR, Appelman HD. Paraganglioma of the gallbladder. Arch Surg 1972; 105: 637-639. [CrossRef]

6. Hirano T. Paraganglioma of the gallbladder: report of a rare case. Am J Gastroenterol 2000; 95: 1607-1608. [CrossRef]

7. Cho YU, Kim JY, Choi SK, Hur YS, Lee KY, Kim SJ, et al. A case of hemorrhagic gallbladder paraganglioma causing acute cholecystitis. Yonsei Med J 2001; 42: 352-356.

8. Wolff M. Paraganglioma of the gallbladder. Arch Surg 1973; 107: 493. [CrossRef]

9. Rodríguez MB, Lozoya R, Allende $E$, Mesa J. Paraganglioma of the gallbladder. Med Clin (Barc) 2006; 127: 158.

10. Mehra S, Chung-Park M. Gallbladder paraganglioma: a case report with review of the literature. Arch Pathol Lab Med 2005; 129 : 523-526.

11. Linnoila RI, Keiser HR, Steinberg SM Lack EE. Histopathology of benign versus malignant sympathoadrenal paraganglioma: clinicopathologic study of 120 cases including unusual histologic features. Hum Pathol 1990; 21: 1168-1180. [CrossRef] 